July 7, 2015

\title{
Cutting the Credit Line: Evidence from Germany*
}

Stefan Goldbach

Deutsche Bundesbank
Volker Nitsch

Technische Universität Darmstadt and CESifo

\begin{abstract}
$\underline{\text { Abstract }}$
The massive decline in international trade in 2008/09 is often attributed to the global deterioration in financial conditions after the bankruptcy of a US investment bank, Lehman Brothers. This paper examines the association between external finance and firm activity in Germany in more detail. In particular, we explore a novel data set that matches a full sample of quarterly bank-firm lending data with detailed information on borrowers and lenders. Our results indicate that foreign sales are insensitive to variations in external finance. While German banks affected by the crisis have significantly reduced their credit supply, we only observe a causal (negative) effect on domestic sales. Exporting firms, in contrast, seem to be particularly good borrowers.
\end{abstract}

JEL Code: E44; E32; G21; F40

Keywords: trade finance; export finance; relationship lending

E-mail: stefan.goldbach@bundesbank.de; nitsch@vwl.tu-darmstadt.de

* We thank Heinz Herrmann for support; Matthias Köhler, Timm Körting and Peter Raupach for helpful discussions; Nathan Cook, Gabriel Felbermayr, Ulrich Grosch, Mathias Hoffmann and participants at presentations in Calgary, Darmstadt, Duisburg, Frankfurt, Göttingen, Honolulu, Leuven and Tübingen for comments; and the Deutsche Bundesbank for the provision of data and hospitality. Discussion Papers represent the authors' personal opinions and do not necessarily reflect the views of the Deutsche Bundesbank or its staff. 


\section{Introduction}

The massive decline in world trade in the fourth quarter of 2008 has led to a growing interest into the procedures of trade financing. Firm practices of funding trade transactions have attracted new attention for at least two reasons. First, cross-border shipping collapsed in the aftermath of the bankruptcy of Lehman Brothers, as global credit conditions tightened dramatically, potentially indicating that shipping activities might have considerable capital needs. ${ }^{1}$ Second, to the extent that external credit is of greater relevance for exports than for domestic sales, this asymmetry may explain why international trade has fallen substantially more than overall economic activity during the crisis. ${ }^{2}$

Based on such reasoning, a number of papers have recently examined the empirical association between financial factors and trade activity. Not surprisingly, there is generally broad support for the hypothesis that shipping is sensitive to financial constraints, possibly in line with other types of business operations. ${ }^{3}$ For French firms, for instance, Bricongne, Fontagné, Gaulier, Taglioni and Vicard (2012) document that firms sizably reduce crossborder shipments if they have experienced an incident of failing to pay its creditors over the past twelve months and, therefore, can be considered to be less creditworthy. Chor and Manova (2012) find that, during the global financial crisis, the decline in exports to the United States was stronger for countries with tighter credit markets and for industries which are more heavily dependent on external finance.

The empirical evidence turns out to be more mixed, however, for the claim that credit constraints affect cross-border shipments and domestic deliveries differently. Amiti and Weinstein (2011) find that the deterioration of the financial position of Japanese banks caused a decline in their client firms' exports relative to their domestic sales. In similar fashion, Ahn, Amiti and Weinstein (2011) argue that trade financing needs differ by mode of transportation, with external financing being particularly important for shipments with long time lags; they

\footnotetext{
${ }^{1}$ While the financial crisis hampered the availability, and raised the cost, of credit, trade may have also been affected by other features of the crisis, such as the sharp correction in equity markets or an increase in uncertainty; see, for instance, Novy and Taylor (2014).

${ }^{2}$ Bems, Johnson, and Yi (2013) note that the decline in real world trade from the first quarter of 2008 to the first quarter of 2009 exceeded the fall in real world GDP by roughly a factor of four.

${ }^{3}$ Aghion, Askenazy, Berman, Cette, and Eymard (2012), for example, analyze the effects of credit constraints on the R\&D investment of firms.
} 
find that goods shipped by sea indeed experienced an increase in prices relative to goods shipped by air or land during the crisis period. ${ }^{4}$

Behrens, Corcos, and Mion (2013), in contrast, note that variables proxying for the financial structure of firms, such as the share of debt in total liabilities, had no measurable effect on changes in firm-level exports-to-turnover ratios in Belgium. For Peru, Paravisini, Rappoport, Schnabl, and Wolfenzon (2015) find that the sensitivity of exports to credit shocks does not vary with measures characteristic for cross-border trade, such as the distance to the destination market, the mode of transportation, or the method of payment.

In this paper, we further explore the empirical association between financial conditions, especially a firm's access to external finance, and firm activity, especially exports. In particular, we aim to identify the causal effect of disruptions in the credit supply on the sales of German firms. Since a firm's use of credit endogenously responds to its production decisions, we apply an instrumental variables approach to identify the effect of capital constraints on firm behavior. Following Paravisini, Rappoport, Schnabl, and Wolfenzon (2015), we use the health of banks as instrument for credit use.

At the heart of our analysis is a novel data set of pair-wise bank-firm relationships in Germany which covers the universe of all individual credit exposures exceeding a threshold of 1.5 million euros at quarterly frequency. To this comprehensive data, we match detailed information on lender and borrower characteristics. Since we are able to examine corporate borrowing by financial institution, a firm's use of external finance from a crisis-affected bank is observed directly; we are, in principle, also able to explore possible patterns of substitution of credit from liquidity-constrained providers to other, potentially more healthy institutions.

Our data spans from 2005 to 2010. This period covers wide fluctuations in financing conditions and firm-level sales, including the global recession of 2008-2009. Most notably, as

\footnotetext{
${ }^{4}$ Ahn (2011) provides a formalization of the idea that cross-border trade transactions are particularly sensitive to financial shocks. Specifically, he argues that international trade finance loans are riskier than domestic trade finance loans. In the model, the banks' screening tests for a borrower, the borrower's domestic trading partners and its foreign trading partners differ in precision levels (or, more precisely, costs). As a result, "international transactions are subject to higher default risks than domestic transactions because the screening test for foreign firms is more likely to misclassify bad firms as good." (Ahn, 2011, p. 17)
} 
shown in Figure 1, economic activity in Germany dropped sharply after the collapse of Lehman Brothers. In line with the literature, this episode will be our main period of interest. ${ }^{5}$

Previewing our main results, we find that exporters were not hit particularly strongly by the credit shortage after the Lehman collapse, even after controlling for other features of the firm such as size, age or industry; the decline in credit supply led to no measurable reduction in export activity.

The remainder of the paper is structured as follows. Section 2 reviews the relevant literature, followed by a detailed description of the various data sources and our matching approach. The heart of our paper is Section 4, which motivates our empirical methodology and presents the results. Finally, Section 5 briefly concludes.

\section{Related Literature}

For a long time, financial aspects of cross-border trade transactions have been discussed, if anything, primarily by financial experts and trade practitioners. Beck, DemirgüçKunt and Maksimovic (2008), for instance, examine patterns of corporate financing, finding that exporting firms use more bank, lease, and trade finance. ${ }^{6}$ Auboin and Meier-Ewert (2003) highlight the role of shortages in the availability of trade finance instruments during the emerging markets crisis of the late 1990s and explore possible institutional responses, from the design of the regulatory framework to the role of regional and multilateral institutions.

With the sudden, severe and synchronized slump in trade, however, in the midst of a financial crisis, issues in trade finance have also become a topic of growing interest for trade economists. To examine the financial vulnerability of cross-border trade transactions, a broad range of issues have been analyzed, including the methods of payment that are typically used in international trade transactions, the determinants of firm-level access to bank-intermediated trade finance, and the external financial dependence of sectors and countries. Bems, Johnson, and Yi (2013) provide an excellent overview of the literature; they argue that credit shocks

\footnotetext{
${ }^{5}$ Similar to other industrial countries, German exports and production fell substantially in 2009 (by $18.3 \%$ and $15.5 \%$, respectively).

${ }^{6}$ Interestingly, while a large empirical literature on firm-level trade consistently shows that exporters display significantly different firm characteristics than domestic sellers, these studies rarely provide systematic evidence for financial variables.
} 
have indeed played a major secondary role in explaining the collapse in trade, accounting for about 20 percent of the decline in trade. ${ }^{7}$

For our analysis, three strands of the literature are of particular relevance. A first line of research is concerned with a general description of bank-firm lending relationships. A prominent example is Berger, Miller, Petersen, Rajan, and Stein (2005), who examine whether differences in the organizational structure of banks have an effect on lending practices. For instance, it is argued that large complex financial institutions have a comparative advantage in standardized activities based on hard information, while small banks are better able to collect and act on soft information. Empirically, they find that larger banks tend to lend to larger and more distant firms, having shorter and less exclusive lending relationships. Memmel, Schmieder, and Stein (2007) examine evidence on relationship lending in Germany. In line with the assumption that a close contact between contracting parties helps to overcome possible information asymmetries, they find that firms which are more likely to suffer from information problems, such as small, young and R\&D intensive companies, are more apt to choose a house bank as their lender; interestingly, they also find that firms with high credit quality often engage in relationship lending (perhaps because of a positive selection process in which firms with low-quality opportunities prefer to borrow from arm's length lenders).

Another set of papers directly examines the importance of credit and financing for export activities, typically exploring the effects of the severe reduction in the availability of external finance during the global financial crisis. Chor and Manova (2012), for instance, use monthly US industry import data to identify channels that are responsible for the sharp decline in trade in the second half of 2008. Focusing on the cost of capital, as approximated by the interbank lending rate, and distinguishing between industries, they find that the higher an industry's dependence on external finance, the higher the decline in trade during the financial crisis. Niepmann and Schmidt-Eisenlohr (2013) take a more specific look at the provision of trade-specific financial instruments. Exploiting the variation in trade finance claims of U.S. banks by destination country and over time, they show that a bank's reduction

\footnotetext{
${ }^{7}$ According to Bems, Johnson, and Yi (2013), changes in expenditure across sectors account for about 65-80 percent of the trade collapse, while the remaining share is attributed to inventory adjustments.
} 
in its supply of destination-specific letters of credits has statistically and economically significant effects on U.S. exports towards this trading partner. ${ }^{8}$

Our analysis is most closely related to recent work that tries to establish causal finance-trade relationships based on micro evidence. In this line of research, papers typically examine detailed information on pair-wise lending relationships, in which firms are matched to the banks that supply them with credit, and then aim to identify the effects of credit shortages on a specific segment of the firms' business activities, exports. However, in view of the difficulties in isolating the various effects (from disentangling the factors of credit supply and demand to separating the consequences for foreign and domestic sales), the identification strategies differ sizably, with data availability often being the main determinant. Amiti and Weinstein (2011), for instance, match micro data from banks and companies in Japan, covering the period from 1990 to 2010 . They identify bank-firm pairs by assigning firms to their main 'reference' bank as listed in a company handbook, with no information on the actual lending relationship. Moreover, their sample is restricted to (at maximum) 15 large, publicly-listed Japanese banks which are supposed to handle most of the firms' transactions. Based on this set-up, Amiti and Weinstein (2011) find that a decline in financial conditions, as measured by a bank's market-to-book value, indeed explains a sizable fraction of the observed decline in a client firm's trade with foreign relative to domestic customers.

Paravisini, Rappoport, Schnabl, and Wolfenzon (2015) examine matched micro data from Peru which allows them to apply an empirical strategy that is refined along at least two dimensions. First, Paravisini, Rappoport, Schnabl, and Wolfenzon (2015) compile detailed information, at monthly frequency, on the outstanding debt of a firm with each bank operating in Peru. As a result, credit shocks by bank-firm pair are directly observable from the data. Second, their access to transactions-level export data, which includes, among others, information on the exporting firm, the product and the destination, allows them to identify (and, therefore, control for) shocks to export demand. After demonstrating that these extensions and modifications to the empirical approach indeed sizably affect the estimation results, Paravisini, Rappoport, Schnabl, and Wolfenzon (2015) find only a moderate effect of credit supply shocks on exports. They estimate that a 10 percent reduction in the supply of credit lowers exports in the following year by 1.95 percent which explains only about 8

\footnotetext{
${ }^{8}$ A number of papers also examine the association between financial health and exports at the firm level, including Muûls (2012) and Behrens, Corcos, and Mion (2013) for Belgium, Bricongne, Fontagne, Gaulier, Taglioni, and Vicard (2010) for France, and Coulibaly, Sapriza, and Zlate (2012) for six Asian countries.
} 
percent of the drop in Peruvian exports during the crisis, thereby attributing the bulk of the decline to non-credit factors.

While Paravisini, Rappoport, Schnabl, and Wolfenzon (2015) have access to exhaustive data, their analysis also faces some limitations. In contrast to Amiti and Weinstein (2011), for instance, they are unable to assess a firm's export response relative to its domestic sales. Also, the financial sector in Peru is not particularly well developed; there are in total only 41 financial institutions operating in Peru, with most credit to exporting firms being concentrated among 13 commercial banks.

Del Prete and Federico (2014) provide additional insights, analyzing bank-firm lending relationships in Italy. Their data set, which is mainly drawn from the Italian credit register, not only covers a large sample of banks; the information on loans also allows to differentiate between (four) types of activities, including loans for exports and loans for imports. Based on this data, Del Prete and Federico (2014) note, for instance, that multiplerelationship banking for exports and imports is very common among Italian firms, with a median firm borrowing from 3 different banks. They also note that trade-related loans account for only a small share (of about 2 percent) of total bank lending.

Turning to the issue of interest, Del Prete and Federico (2014) use a bank's exposure to foreign funding as their measure of credit supply. Similar to Paravisini, Rappoport, Schnabl, and Wolfenzon (2015), they find that banks that relied heavily on foreign funding have reduced their lending during crisis times relative to non-exposed banks. Interestingly, however, this effect differs sizably across the types of loans, with no measurable association between a bank's share of foreign funding and its supply of trade finance loans. Still, when Del Prete and Federico (2014) examine the effect of credit supply on firm activities, they find that firms borrowing from banks that are more exposed to a negative funding shock exhibit a significantly worse export performance than firms borrowing from more healthy banks, although the effect is small in magnitude. Domestic sales, in contrast, turn out to be unaffected by bank-firm lending patterns.

We contribute to this literature along various lines. Similar to previous studies, our empirical strategy is primarily determined by the features of the data available to us. For instance, our raw data set is extremely large, comprising the full universe of large-scale lending relationships in Germany at quarterly frequency; as a result, we are able to explore hundreds of thousands bank-firm pairs. Moreover, since the German government has aimed to 
stabilize the financial system, among others, by taking measures that supported individual banks (either by rescuing them directly or increasing their resilience through restructuring), we identify troubled credit institutions directly.

\section{Data Description}

To analyze bank-firm relationships in Germany, we use three different data sets, all provided by the Deutsche Bundesbank. The micro data are confidential; they are only accessible, often in anonymized form, at the headquarter of the Bundesbank in Frankfurt, Germany. We begin by describing the data sources in detail.

Our main source of data is the Bundesbank's credit register, named MiMiK. This register regularly collects information on individual lending relationships between borrowers and lenders. The data set is complete; all banking institutions based in Germany are required to report their large exposures to the Deutsche Bundesbank in order to allow the central bank to monitor indebtedness. ${ }^{9}$ While the register was originally established in 1934, reporting requirements have been occasionally adjusted to take account of inflation (raising the regulatory reporting threshold) and structural changes in banking and financing techniques (e.g., adding credit derivatives to the definition of credit exposure). Schmieder (2006) provides a more detailed description of the database.

In its current version, the German credit register contains information on all loans in excess of 1.5 million euro granted by banks in Germany to firms worldwide. For each bankfirm relationship, the size of the total credit exposure (both on and off balance sheet) is provided, along with the name and address of the borrower as well as information on the lender (in the form of an internal bank identification number). The frequency of the data is quarterly, with information provided at the end of the quarter. Our sample covers the period from 2005 to 2010 .

The second source of information is the corporate balance sheets database of the Bundesbank, Ustan. The Bundesbank has collected, mainly for refinancing purposes, extensive data on individual firms. The data are often taken from financial statements, but may also have been obtained from a mandatory questionnaire, based on balance sheet and

\footnotetext{
${ }^{9}$ See section 14 of the German Banking Act (Kreditwesengesetz).
} 
profit and loss accounts data. Most notably for our purposes, the database includes information on firms' domestic and export sales.

The corporate balance sheets data are available on an annual basis. We merge the data with our information from the credit register by the corresponding year (such that annual firm data is matched with the loan data in each of the four quarters in a given year). Unfortunately, the firm identifiers differ between the two data sets. Therefore, we develop a propensity score matching algorithm, based on the name of the firm, its legal form and its location; Memmel, Schmieder and Stein (2007) use a similar approach. In the practical implementation of this matching procedure, we use a cut-off minimum score of 90 percent. In total, the matching quote between the two data sets is approximately 55 percent.

Finally, we use data from the Bundesbank's prudential information system on banks, BAKIS. The database contains information on a wide range of bank characteristics, mainly taken from financial statements and quantitative audit reports. Regular reports to the Bundesbank (as a German financial supervisory authority) are mandatory for banks. BAKIS data are on annual frequency, reaching back to 1993.

Table 1 provides an overview of the various combinations of matched data sets. There are about 1 million entries of pair-wise bank-firm lending relationships in the Bundesbank's credit register for the 24 quarters from 2005 to 2010. These entries cover about 14,900 loantaking entities and more than 2,200 loan-providing institutions, for most of which we also have complementary information on firm and bank characteristics, respectively. While the number of loans decreases by about a quarter in the matched data sets, the number of firms and banks in the sample is considerably more stable. ${ }^{10}$ Most notably, for subsamples based on the matched data sets, the key features of the bank-firm relationships do not differ sizably from the raw data. For instance, the pair-wise credit exposure consistently averages at about 8 million euro.

Reviewing our data in more detail, Figure 2 shows that the financing conditions have indeed deteriorated in Germany during the global financial crisis. After a strong expansion in previous quarters, total credit measurably declined in 2009; while the number of loans continued to increase, its pace of expansion slowed considerably. Appendix 1 provides

\footnotetext{
${ }^{10}$ For some banks, no information on bank characteristics is available from BAKIS because of bank mergers. For instance, Germany's second largest bank, Commerzbank, announced that it would acquire Dresdner Bank, then the country's number seven, in August 2008; the merger took place in May 2009, and Dresdner Bank ceased to be an independent entity.
} 
additional (graphical) information about the evolution of bank-firm credit relationships in our sample.

Moreover, it is reassuring to note that our firm-level data follows aggregate developments quite well. As shown in Figure 3, there is a (remarkably) close match between official statistical data on measures of economic activity and the corresponding variables in our matched micro data sets. ${ }^{11}$

\section{Empirical Analysis}

To examine whether financing conditions have a measurable causal effect on firm activity, we proceed in steps.

\subsection{Reduced-Form Estimation}

We begin our analysis by using the following first-differences model:

$$
\Delta \ln \left(\operatorname{Exports}_{\mathrm{ijt}}\right)=\alpha+\beta \Delta \ln \left(\operatorname{Loan}_{\mathrm{it}-1}\right)+\phi_{\mathrm{jt}}+\varepsilon_{\mathrm{ijt}}
$$

where Exports $\mathrm{ijt}_{\mathrm{ijt}}$ are foreign sales of firm $\mathrm{i}$ in industry $\mathrm{j}$ at time $\mathrm{t}, \operatorname{Loan}_{\mathrm{it}-1}$ is the total bank credit exposure to firm $i$ in the previous period, and we include a full set of industry-time specific $\left(\phi_{\mathrm{jt}}\right)$ fixed effects. As in Amiti and Weinstein (2011), we address obvious endogeneity concerns in two ways. First, we lag the amount of bank credit such that a firm's use of external finance is not affected by its current production decisions. Second, to the extent that a firm's growth performance is determined by industry-wide developments (and, therefore, largely unrelated to financial conditions), the $\phi_{\mathrm{jt}}$ 's are targeted to capture these effects; they

\footnotetext{
${ }^{11}$ In total, foreign sales of firms in our data set account for about 40 percent of Germany's exports. For an informed interpretation of this number, it should be noted that international trade is typically highly concentrated across firms; see, for example, Bernard, Jensen, Redding, and Schott (2007). Large firms, however, have access to and often use alternative means of financing (other than bank credit), such as capital market instruments. Some major German exporting firms, such as Siemens and Volkswagen, are even providers of financial services.
} 
control for factors common to all firms in a given industry at a particular point in time such that our empirical findings refer to the within-industry-year variation in firm behavior. ${ }^{12}$

Table 2 presents the baseline estimation results for various specifications of equation (1), using annual data for the period from 2005 through $2010 .{ }^{13}$ Columns (1)-(7) of the table report the results for the analysis of aggregate loans by firm (thereby allowing firms to substitute credit providers); columns (8) and (9) tabulate analogous estimation results derived from our (larger) sample of individual bank-firm relationships. Our default estimation of the effect of credit supply on exports is reported in column (1). For this specification, our estimates indicate that changes in export sales are basically unrelated to a firm's use of external finance. The estimated coefficient on the change in a firm's total stock of bank credit is statistically indifferent from zero and even takes a negative sign. There is also no evidence that export activities respond more sensitively to financial conditions than domestic sales. When we use the change in a firm's export share (instead of its export sales) as dependent variable, similarly weak results are obtained (column 2).

In a next step, we explore the relevance of bank credit for other measures of firm activity. Columns (3) and (4) tabulate estimation results for domestic sales and total sales as regressands. For both measures, interestingly, we observe a strong positive association between the use of bank finance and firm sales. Still, the magnitude of the effects seems to be negligible; the point estimates of about 0.01 indicate that a reduction in the growth rate of bank credit by 10 percent is associated with a decline in sales growth by about 0.1 percent in the following year. Moreover, splitting the sample by a firm's export status has only moderate effects on the estimation results; total sales are, if anything, somewhat more dependent on external finance for non-exporters than for exporting firms (columns 5 and 6).

In the final three columns of Table 2, we report additional robustness checks on the relationship between credit use and exports with somewhat mixed results. Our default estimate remains virtually unchanged when we additionally control for (unobserved) timeinvariant firm characteristics, using firm-specific fixed effects (column 7). The estimation

\footnotetext{
${ }^{12}$ There are 52 industries at the 2-digit level of the German Classification of Economic Activities, Edition 2003 (WZ 2003); see https://www.destatis.de/DE/Methoden/Klassifikationen/GueterWirtschaftklassifikationen/Con tent75/KlassifikationWZ2003.html for details.

${ }^{13}$ We compute the annual amount of credit outstanding to a firm as the arithmetic average of quarterly bank exposures in a given year. Alternatively, we experiment with using a firm's outstanding debt at the end of the year, without much effect on the results.
} 
results turn out to be stronger, however, when changes in the stock of credit at the individual bank-firm level (instead of a firm's total credit) are analyzed. For this larger sample, the estimate of $\beta$ becomes positive and (with a t-statistic of 1.8) marginally significant at the 10 percent level, potentially indicating that exporters only manage to partially substitute credit.

\subsection{Instrumental Variable Analysis}

While the use of lagged credit growth and industry-time fixed effects may provide a useful first attempt to deal with problems of endogeneity, these assumptions alone are not sufficient to establish causality. First, there could still be concerns related to reverse causality from firm activity to credit use. For example, firms may already start to reduce their demand for bank credit when they expect a potential future deterioration of business conditions. Second, omitted variables may be an issue. Although industry-time fixed effects aim to control for variations in demand, it could still be argued that external factors (such as the global financial crisis) induced both a fall in bank lending and firm sales.

Therefore, following the literature, we next apply an instrumental variables approach to estimate the causal effect of credit disruptions on production. Specifically, we argue that the financial strength of a bank, its 'health', may be used as an instrument of credit use. More precisely, we hypothesize that banks whose financial health deteriorates can be expected to reduce their credit exposure relative to more healthy institutions such that firms lending from those banks are likely to suffer from credit reductions.

The difficulty, then, is to assess the health of banks. Amiti and Weinstein (2011) borrow their evaluations from the stock market; they use the market-to-book value of banks, which automatically restricts their focus on publicly listed institutions. Paravisini, Rappoport, Schnabl, and Wolfenzon (2015) and Del Prete and Federico (2014) propose another measure. Limiting their attention to the global financial crisis, they use the banks' share of foreign funding as identification variable, arguing that as banks receive a larger share of their funding from abroad, they are more strongly 'affected' by the crisis. ${ }^{14}$ Rose and Wieladek (2014)

\footnotetext{
${ }^{14}$ For a small open economy such as Peru, this approach seems reasonable. When firms receive funding mostly from one or two banks, financial shocks from outside can easily influence firm behavior.
} 
identify British banks that were subject to public intervention during the crisis based on a Google search.

For our sample of German banks, we assess the health of a financial institution based on information from the special financial market stabilization fund SoFFin ("Sonderfonds Finanzmarktstabilisierung"). ${ }^{15}$ This program was established by the German government on October 17, 2008, about one month after the collapse of Lehman Brothers, with the purpose to stabilize and restore confidence in the financial system in Germany. Initially structured as an agency, SoFFin had various instruments at its disposal. Funds were used, for instance, to rescue banks directly, where financially distressed banks received capital injections in the form of guarantees and recapitalization. Other measures were targeted at increasing the longterm resilience of financial institutions; these measures ranged from an outright restructuring of institutions to a redefinition of individual business models and a transfer of risks to winddown agencies. In our empirical implementation, we identify banks as crisis-hit financial institutions if they have received government support through SoFFin. According to this measure, ten German banks are identified which have used the rescue fund directly; the banks are listed in Appendix 2. A wider definition of this measure includes, in addition, the subsidiaries of these banks which raises the number of financially distressed institutions to 47 .

We also experiment with another measure of bank health. In particular, we classify banks as affected by the crisis if they are covered by the stress test exercise of the European Banking Authority (EBA). While coverage by the EBA is predominantly an indicator of bank size, one might also argue that banks, in order to pass the regulatory stress testing, take preventive action to reduce risks. More importantly, especially large German banks have pursued risky business strategies before the crisis. As it turns out, there is indeed considerable overlap of the lists as shown in Appendix 2. As before, we also extend this measure to additionally include the subsidiaries of banks on the EBA list which raises the number of financial institutions from 12 to 104.

The measures of bank health are described in more detail in Table 3. The upper panel of the table presents summary statistics for our full sample. As shown, the banks classified as weak, although small in number, represent a sizable share of (large credit) lending. For instance, the few banks which are large enough to be covered by the EBA (along with their subsidiaries) account for about 45 percent of all credit relationships in our sample. Moreover,

${ }^{15}$ See http://www.fmsa.de/en/fmsa/soffin/index.html for details. 
the correlation matrix, tabulated in the lower panel, shows that there is some reasonable variation across our indicators of bank health.

Before we apply IV estimation to identify the impact of the credit supply shock on firm activity, we inspect the sensitivity of bank lending to our measures of bank health during the crisis episode. Specifically, we estimate variants of the following specification:

$$
\ln \left(\operatorname{Loan}_{\mathrm{ik}}^{2009}\right)-\ln \left(\operatorname{Loan}_{\mathrm{ik}}^{2008}\right)=\delta \text { BankHealth }_{\mathrm{k}}+\eta_{\mathrm{i}}+\varepsilon_{\mathrm{ik}}
$$

where BankHealth $\mathrm{k}_{\mathrm{k}}$ is a binary dummy variable that takes the value of one if bank $\mathrm{k}$ is classified as crisis-affected (and zero otherwise). Following Khwaja and Mian (2008) and others, our regression model also includes a comprehensive set of firm fixed effects $\left(\eta_{i}\right)$ such that the within-firm estimator identifies differences in the amount of lending by banks to the same firm that have emerged after the collapse of Lehman Brothers. ${ }^{16}$

Table 4 presents the results. Each column contains estimates from a different regression, with our definition of crisis-affected banks varying across columns. Three observations appear particularly noteworthy. First, there is convincing evidence that banks covered by SoFFin have sizably reduced their lending during the crisis. The estimated $\delta$ coefficients are consistently negative and statistically significant, and imply that banks on the SoFFin list have cut their credit exposure by about 8-10 percent relative to other banks. These estimates are roughly in line with, although slightly smaller than, the findings in Paravisini, Rappoport, Schnabl, and Wolfenzon (2015). The upper graph of Figure 4 provides accompanying graphical evidence. Second, the reduction in credit applies particularly to the main bank. The effect of the crisis on lending turns out to be weaker for our more encompassing list of SoFFin banks, indicating that subsidiaries which often operate in different markets and pursue different strategies than the parent bank take independent business decisions. Third, there is, at best, only suggestive evidence of a change in lending behavior for banks subject to supervision through the European Banking Authority. Although

\footnotetext{
${ }^{16}$ Since the bank-firm lending data are available at quarterly frequency, we could, in principle, define the pre- and post-crisis periods more appropriately as Q4/2007-Q3/2008 and Q4/2008-Q3/2009, respectively. For this specification, however, the results turn out to be qualitatively similar.
} 
negative and economically relevant, the estimates of $\delta$ are of borderline statistical significance.

Next, we analyze the effects of a credit supply shock on firm-level activities. However, in contrast to our baseline specification, we now restrict our attention exclusively on the crisis episode. That is, we estimate:

$$
\ln \left(\text { Exports }_{\mathrm{ij}}{ }^{2009}\right)-\ln \left(\text { Exports }_{\mathrm{ij}}{ }^{2008}\right)=\alpha^{\prime}+\beta^{\prime}\left[\ln \left(\operatorname{Loan}_{\mathrm{ik}}{ }^{2009}\right)-\ln \left(\operatorname{Loan}_{\mathrm{ik}}{ }^{2008}\right)\right]+\phi_{\mathrm{jt}}+\varepsilon_{\mathrm{ijt}}
$$

This slightly modified version of equation (1) allows us to use our measure of bank health as an instrument for the credit supply shock to the firm.

We provide the results of ordinary least squares (OLS) and instrumental variables (IV) estimations of equation (3), using official government support through SoFFin as our identification variable for crisis-affected banks, in Table 5. As before, we begin with our main firm activity measure of interest, foreign sales, and tabulate the results in columns 1 and 2. In line with our benchmark results, the OLS estimate of the export elasticity to credit supply is close to zero and even takes a negative sign. The IV estimate of the elasticity, in contrast, is positive and economically sizable, but statistically indifferent from zero at conventional levels.

The results turn out to be much stronger for other measures of firm activity, domestic sales and total sales, thereby again confirming our earlier findings. However, while the OLS estimates of about 0.010 indicate only a small positive effect of credit supply on sales, the IV estimates are about 8 times larger - a discrepancy in magnitude that is remarkably similar to the findings in Paravisini, Rappoport, Schnabl, and Wolfenzon (2015). The point estimates of 0.097 (0.076) for domestic (total) sales indicate that a reduction in the credit supply by 10 percent leads to a decline in sales by 0.97 (0.76) percentage points.

In columns 7 and 8 of Table 5, we pool foreign and domestic sales. Following Paravisini, Rappoport, Schnabl, and Wolfenzon (2015), we argue that a full set of industrydestination fixed effects absorbs any variation in demand, such that the estimates of $\beta$ ' capture the effect of changes in credit supply on sales. However, the results turn out to be not 
particularly encouraging. While the estimated elasticities are of comparable magnitude, the point estimates are not statistically significant.

We also modify our analysis along various dimensions. The results of selected robustness checks are reported in Table 6 . In a first exercise, we augment our baseline model with additional measures on firm characteristics, without much effect. Our firm controls include log employment, log age, and binary dummy variables for multinationals, legal status of the firm and firm location. Next, we restrict our sample to exporting firms only. Reassuringly, our results turn out to be again remarkably robust. ${ }^{17}$ Finally, we vary our instrumental variable. Not surprisingly, while the first stage is weaker for these variables, the IV estimates are larger.

\section{$\underline{4.3 \text { Bank Lending Behavior }}$}

In a final exercise, we explore the effects of a firm's export status on the strength of bank-firm relationships in more detail. Specifically, it has been argued that exports are particularly sensitive to external finance as cross-border trade takes longer and involves greater risk than domestic shipments. Goldbach and Nitsch (2014) also show that exporting firms take out significantly larger loans than non-exporters, holding other things constant.

While this demand-driven perspective seems intuitive, and there is some empirical evidence in support of these hypotheses (see, for instance, Amiti and Weinstein [2011]), the banks' perspective may be equally important for understanding the role of firm-specific characteristics for lending. It may be argued, for instance, that banks consider exporters, despite their greater financing needs, as high quality, low risk clients, as they are typically more productive than domestic sellers. Consequently, banks would seek to extend their lending to exporting firms during times of crisis, thereby easing the firms' financing pressure. Del Prete and Federico (2014), for instance, find that Italian banks significantly reduced their

\footnotetext{
${ }^{17}$ In unreported results, we also split our sample by the main destination of exports at the industry level, distinguishing between intra-European Union shipments and shipments outside the European Union. In particular, it may be argued that, due to the European Union's single market, exports to European Union countries are fundamentally different from exports to other countries. However, the estimation results for the two subsamples, separating industries into those with above and below median export shares to the European Union, turn out to be qualitatively similar to the full sample results.
} 
overall credit exposure during the crisis, while their hand-out of trade finance loans remained largely unchanged. ${ }^{18}$

We analyze any potential divergence in bank lending behavior towards exporting firms and non-exporters using a difference- in-differences approach. In particular, we modify specification (2), which examines emerging differences in lending patterns between crisisaffected and more healthy banks after the shock, in a way that allows us to additionally estimate the effect of individual firm characteristics. More specifically, firm fixed effects are replaced with industry fixed effects, and a measure of the borrowing firm's export status is added; an interaction term then identifies the effect of bank health on the lending channel for exporters and non-exporters. ${ }^{19}$ Since the trends in lending did not differ by bank health before the crisis, this estimate does not reflect any preexisting differentials in bank lending patterns; see Figure 4.

Estimation results are reported in Table 7. As before, we proceed stepwise, examining various measures and specifications. However, for the sake of brevity, we only present results for specifications using our preferred measure of bank health, a bank's need for and use of government support through the SoFFin program.

Column 1 tabulates the estimates for a parsimoniously specified difference-indifferences model in which we identify a firm's export activity with a binary exporter dummy. Reassuringly, the results strongly confirm our previous finding that SoFFin banks significantly reduced their lending exposure relative to other banks. The (negative) coefficient on the SoFFin dummy even increases in magnitude to -0.15 , compared to -0.10 for our results based on the full sample in Table 4, providing a first indication that the crisis-induced cut in bank lending may have indeed affected domestic sellers more strongly than exporting firms. More direct evidence that exporters experience a smaller impact of the bank lending channel is provided by the interaction coefficient which takes a significantly positive value. The point estimate of 0.08 implies that lending from banks on the SoFFin list to exporting firms declines 7.3 percent (versus 15.3 percent for domestic sellers). As a result, the drop in lending from liquidity-constrained financial institutions is only half as large for exporters than for domestic sellers.

${ }^{18}$ Del Prete and Federico (2014) argue that this finding is explained by a lower risk of moral hazard in transaction banking activities, since the financial funds are used for specific transactions (and therefore backed by the underlying receivables).

${ }^{19}$ Khwaja and Mian (2008) follow a similar approach to analyze differences in the lending channel for large and small firms. 
Column 2 presents analogous estimation results when the exporter dummy is replaced with a firm's share of foreign sales in total sales as our indicator of export activity. With this modification, however, the results turn out to be qualitatively unchanged. Columns 3 and 4 show that the results also remain robust to the inclusion of additional controls for firm characteristics such as the firm's size, age, ownership type and geographic location.

In addition to the effect of poor bank health on changes in loan size (i.e., variations in lending along the intensive margin), we also examine potential differences in lending behavior along the extensive margin. In particular, we ask whether troubled banks have cut their customer base in times of crisis and stopped lending to firms, notably exporters, completely. Similarly, banks on the SoFFin list may have been excessively conservative when making lending decisions for new customers. To analyze these issues, we first replace the change in log loan amount with a binary dummy variable that takes the value of one for bankfirm pairs that newly show up in the German credit register in 2009 and is zero otherwise ('entry') as our dependent variable and, next, we use an analogously constructed dummy variable for bank-firm pairs that disappear from the credit register after the shock ('exit') as regressand. ${ }^{20}$

The results are reported in the remaining four columns of Table 7. To save space, only the set of estimates for the parsimoniously specified differences-in-differences model is tabulated; the results for the specification with additional firm-level controls turn out to be virtually identical. In addition, it should be noted that the estimation results are remarkably consistent across columns.

Reviewing the results presented in columns 5 through 8 in more detail, there are, at least, two notable findings. For one thing, turning directly to our variable of interest, the results show that there is no significant divergence in lending patterns between SoFFin and non-SoFFin banks. More specifically, the estimated coefficients on the interaction terms are always statistically indifferent from zero, implying that banks that received public assistance through the SoFFin program have not reshuffled their portfolio of customers in favor of exporters or non-exporters to an extent that sizably deviates from the lending behavior of other banks. In terms of overall outcomes, in contrast, we obtain (with one exception) statistically significant coefficient estimates on our measure of a firm's export activity. For instance, the point estimates on the exporter dummy indicate that exporting firms are, on

\footnotetext{
${ }^{20}$ Following Khwaja and Mian (2008), we use a linear regression specification; a Probit estimator provides similar results.
} 
average, less likely to obtain a new loan and are more likely to exit a relationship in 2009. Since the coefficients on these variables, however, reflect lending by all banks (and, thus, an economy-wide phenomenon), they capture changes in firm-specific credit demand that are not yet absorbed by the industry fixed effects.

The lower graph of Figure 4 provides an illustration of these results. For exporting firms, shown in the left panel of the graph, we observe a sizable decline in bank lending during the financial crisis. However, there is no differential treatment of exporters by bank health; loans to exporters are reduced irrespective of whether a bank was hit hard by the crisis or not, indicating that the drop in lending is mainly driven by the firms' demand for credit. A different pattern is observed for non-exporting firms, as shown in the right panel of the graph. Lending to these firms by financially troubled banks exhibits a strong decrease relative to lending by banks which were less liquidity constrained. Since there is no difference in lending patterns between the two sets of banks before the crisis, this result indicates that the decline in lending is primarily due to changes in banks' supply of credit, thereby illustrating the bank lending channel.

Overall, and in line with the empirical observations for Italy in Del Prete and Federico (2014), our findings suggest that the credit decisions of banks are probably more complex than simple models seem to imply in which banks are assumed to consider the cross-border activities of their clients as more risky business than comparable domestic transactions.

\section{Conclusions}

The sudden stand-still in world trade after the collapse of Lehman Brothers in September 2008 is often labeled the 'Great Trade Collapse'. Puzzled by this dramatic and unexpected decline in cross-border trade activity, a number of recent papers aim to explain this pattern, applying different data sources. Amiti and Weinstein (2011), for instance, identify a causal link between trade and financial conditions for Japanese firms; the deterioration in financial conditions of banks can partly explain the large drop in trade flows. Behrens, Corcos, and Mion (2013), in contrast, conclude that financial conditions are not the most important factor for explaining the trade pattern for Belgian firms; they argue that the fall in demand has had a much stronger impact. Bricongne, Fontagne, Gaulier, Taglioni and Vicard (2012) argue that lower demand and the intensive margin for large firms are the most important determinants. As a result, empirical findings appear generally mixed. 
Based on three different micro data sets from the Deutsche Bundesbank, we identify various linkages between firms and banks in Germany. Exports turn out to be insensitive to variations in external finance. While German banks affected by the crisis have significantly reduced their credit supply, we only observe a causal (negative) effect on domestic sales. Exporting firms, in contrast, seem to be particularly good borrowers, which have been offered alternative financing options.

\section{$\underline{\text { References: }}$}

Aghion, Philippe, Philippe Askenazy, Nicolas Berman, Gilbert Cette, and Laurent Eymard. 2012. "Credit Constraints and the Cyclicality of R\&D Investment: Evidence from France," Journal of the European Economic Association. 10 (October): 1001-1024.

Ahn, JaeBin. 2011. “A Theory of Domestic and International Trade Finance," IMF Working Paper $11 / 262$.

Ahn, JaeBin, Mary Amiti, and David E. Weinstein. 2011. "Trade Finance and the Great Trade Collapse," American Economic Review. 101 (May): 298-302.

Amiti, Mary and David E. Weinstein. 2011. "Exports and Financial Shocks," Quarterly Journal of Economics. 126 (November): 1841-1877.

Antràs, Pol and C. Fritz Foley, 2015. "Poultry in Motion: A Study of International Trade Finance Practices," Journal of Political Economy. (forthcoming).

Auboin, Marc. 2007. "Boosting Trade Finance in Developing Countries: What Link with the WTO?” WTO Staff Working Paper ERSD-2007-04.

Auboin, Marc and Moritz Meier-Ewert. 2003. Improving the Availability of Trade Finance during Financial Crises. Geneva: WTO.

Beck, Thorsten, Asli Demirgüç-Kunt, and Vojislav Maksimovic. 2008. "Financing Patterns around the World: Are Small Firms Different?” Journal of Financial Economics. 89 (September): 467-487.

Behrens, Kristian, Gregory Corcos, and Giordano Mion. 2013. "Trade Crisis? What Trade Crisis?" Review of Economics and Statistics. 95 (May): 702-709.

Bems, Rudolfs, Robert C. Johnson, and Kei-Mu Yi. 2013. "The Great Trade Collapse," Annual Review of Economics. 5: 375-400.

Berger, Allen N., Nathan H. Miller, Mitchell A. Petersen, Raghuram G. Rajan, and Jeremy C. Stein. 2005. "Does Function Follow Organizational Form? Evidence from the Lending Practices of Large and Small Banks," Journal of Financial Economics. 76 (May): 237-269.

Berman, Nicolas and Philippe Martin. 2010. "The Vulnerability of Sub-Saharan Africa to the Financial Crisis: The Case of Trade," EUI-RSCAS Working Paper 2010-15.

Bernard, Andrew B., J. Bradford Jensen, Stephen J. Redding, and Peter K. Schott. 2007. "Firms in International Trade," Journal of Economic Perspectives. 21 (Summer): 105-130. 
Bricongne, Jean-Charles, Lionel Fontagné, Guillaume Gaulier, Daria Taglioni, and Vincent Vicard. 2012. "Firms and the Global Crisis: French Exports in the Turmoil," Journal of International Economics. 87 (May): 134-146.

Chor, Davin, and Kalina Manova. 2012. "Off the Cliff and Back? Credit Conditions and International Trade During the Global Financial Crisis," Journal of International Economics. 87 (May): 117-133.

Coulibaly, Brahima, Horacio Sapriza, and Andrei Zlate. 2012. "Financial Frictions, Trade Credit, and the 2008-09 Global Financial Crisis," Board of Governors of the Federal Reserve System International Finance Discussion Papers 1020r.

Del Prete, Silvia and Stefano Federico. 2014. "Trade and Finance. Is There More Than Just 'Trade Finance'? Evidence from Matched Bank-Firm Data," Banca d'Italia Working Paper 948.

Freund, Caroline. 2009. "The Trade Response to Global Downturns: Historical Evidence," World Bank Policy Research Working Paper 5015.

Goldbach, Stefan and Volker Nitsch. 2014. "Extra Credit: Bank Finance and Firm Export Status in Germany," The World Economy. 37 (July): 883-891.

Iacovone, Leonardo and Veronika Zavacka. 2009. "Banking Crises and Exports: Lessons from the Past," World Bank Policy Research Working Paper 5016.

Khwaja, Asim Ijaz and Atif Mian. 2008 "Tracing the Impact of Bank Liquidity Shocks: Evidence from an Emerging Market," American Economic Review. 98 (September): 14131442.

Memmel, Christoph, Christian Schmieder, and Ingrid Stein. 2007. "Relationship Lending: Empirical Evidence for Germany," Deutsche Bundesbank Discussion Paper 14/2007.

Muûls, Mirabelle. 2012. "Exporters, Importers and Credit Constraints," CEP Discussion Paper 1169.

Niepmann, Friederike and Tim Schmidt-Eisenlohr. 2013. "No Guarantees, No Trade: How Banks Affect Export Patterns," Federal Reserve Bank of New York Staff Reports 659.

Novy, Dennis and Alan M. Taylor. 2014. "Trade and Uncertainty," NBER Working Paper \#19941.

Paravisini, Daniel, Veronica Rappoport, Philipp Schnabl, and Daniel Wolfenzon. 2015. "Dissecting the Effect of Credit Supply on Trade: Evidence from Matched Credit-Export Data," Review of Economic Studies. 82 (January): 333-359.

Rose, Andrew K. and Tomasz Wieladek. 2014. "Financial Protectionism? First Tests," Journal of Finance. 69 (October): 2127-2149.

Rosenbaum, Paul R. and Donald B. Rubin. 1983. "The Central Role of the Propensity Score in Observatonal Studies for Causal Effects," Biometrika. 70 (April): 41-55.

Schmidt-Eisenlohr, Tim. 2013. "Towards a Theory of Trade Finance,” Journal of International Economics. 91 (September): 96-112. 
Schmieder, Christian. 2006. "The Deutsche Bundesbank's Large Credit Database (BAKIS-M and MiMiK," Schmollers Jahrbuch. 126: 653-663. 
Figure 1: Exports and Production in Germany, 2005-2011

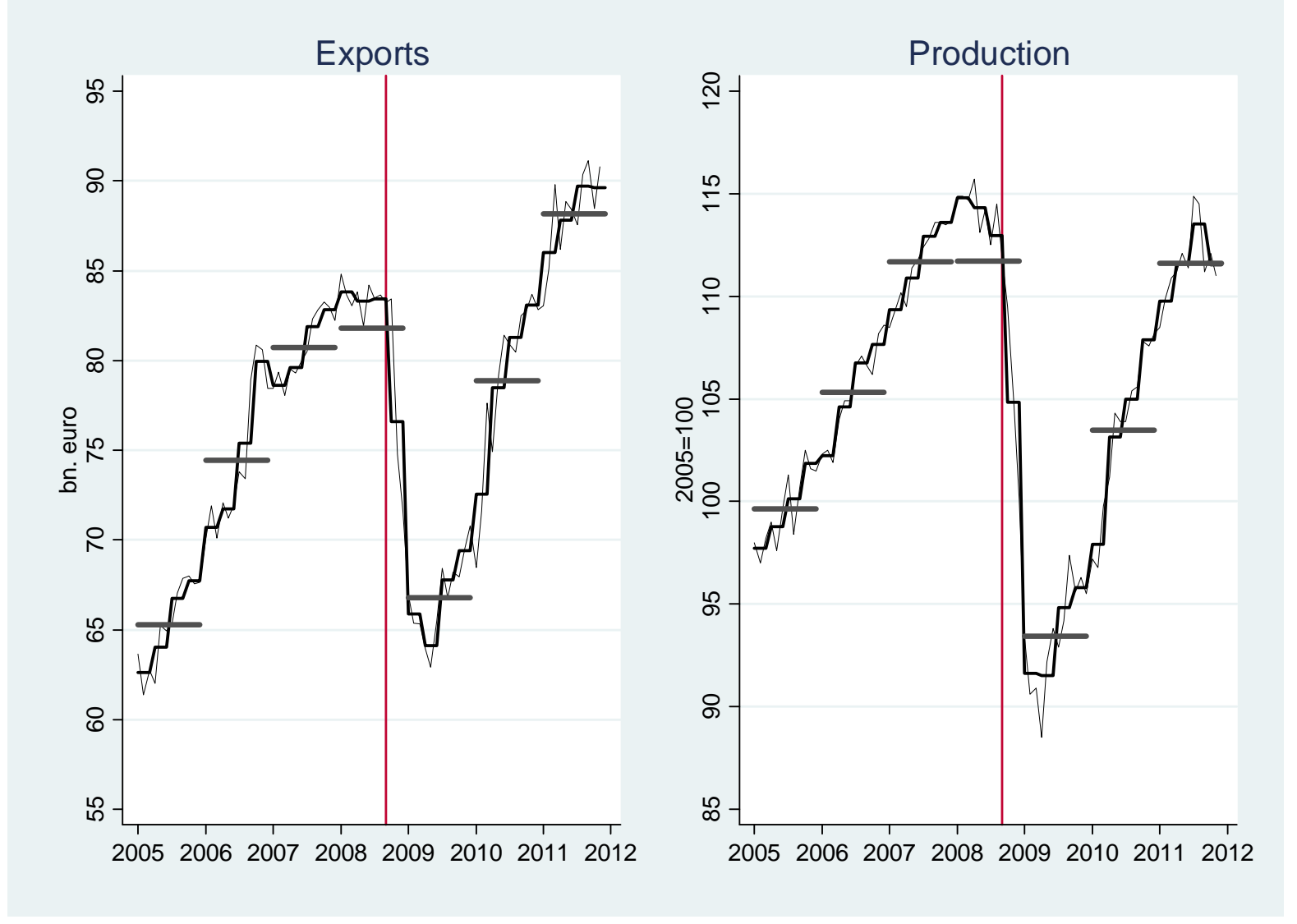

Notes: The graphs plot seasonally adjusted monthly data as well as quarterly and yearly averages.

Source: Deutsche Bundesbank 
Figure 2: Bank-Firm Credit Relationships in Germany, 2005-2010

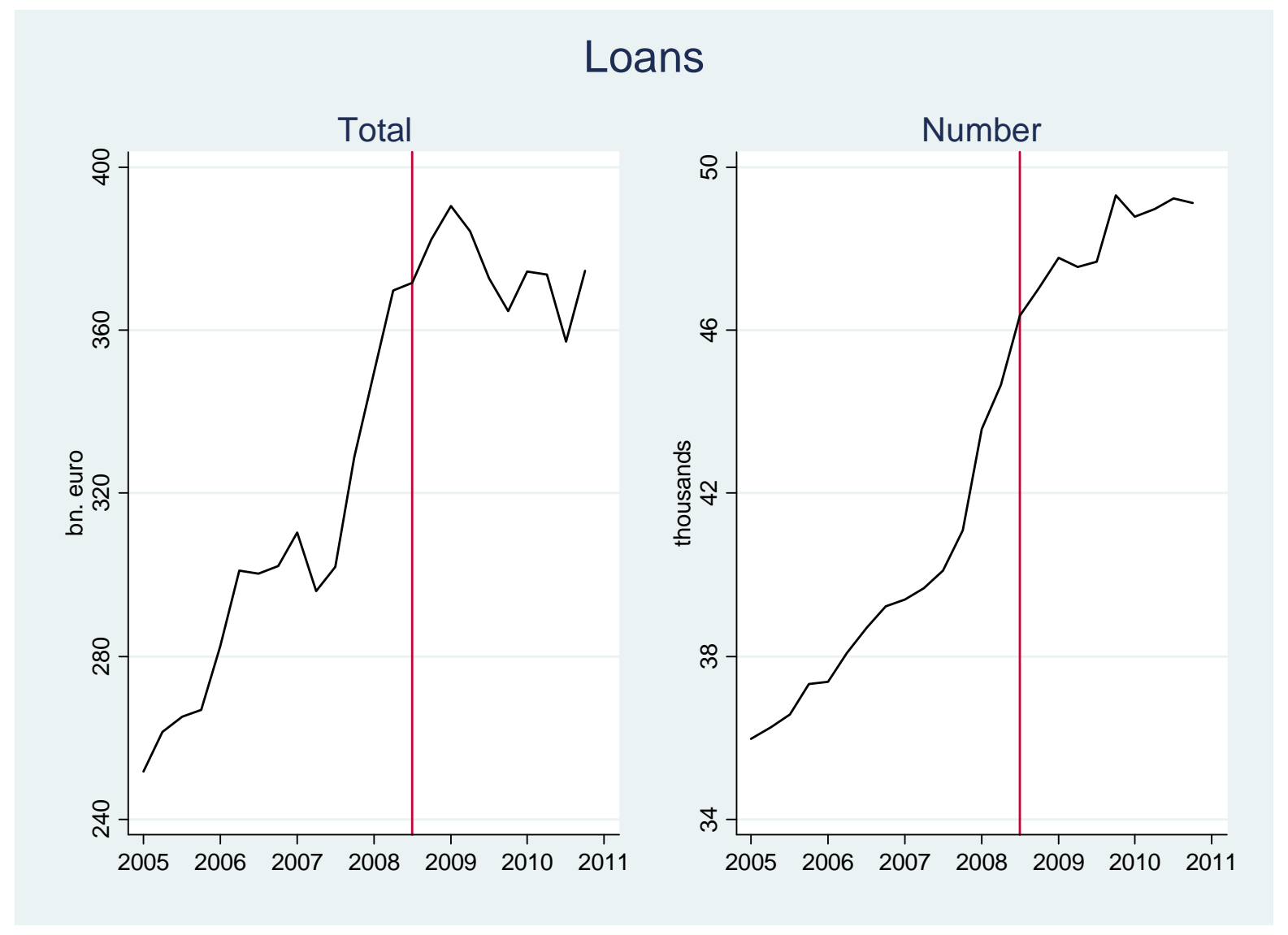

Notes: The quarterly data are taken from the Bundesbank's credit register (covering exposures in excess of $1.5 \mathrm{~m}$ euro).

Source: Deutsche Bundesbank 
Figure 3: Firm-Level and Aggregate Data
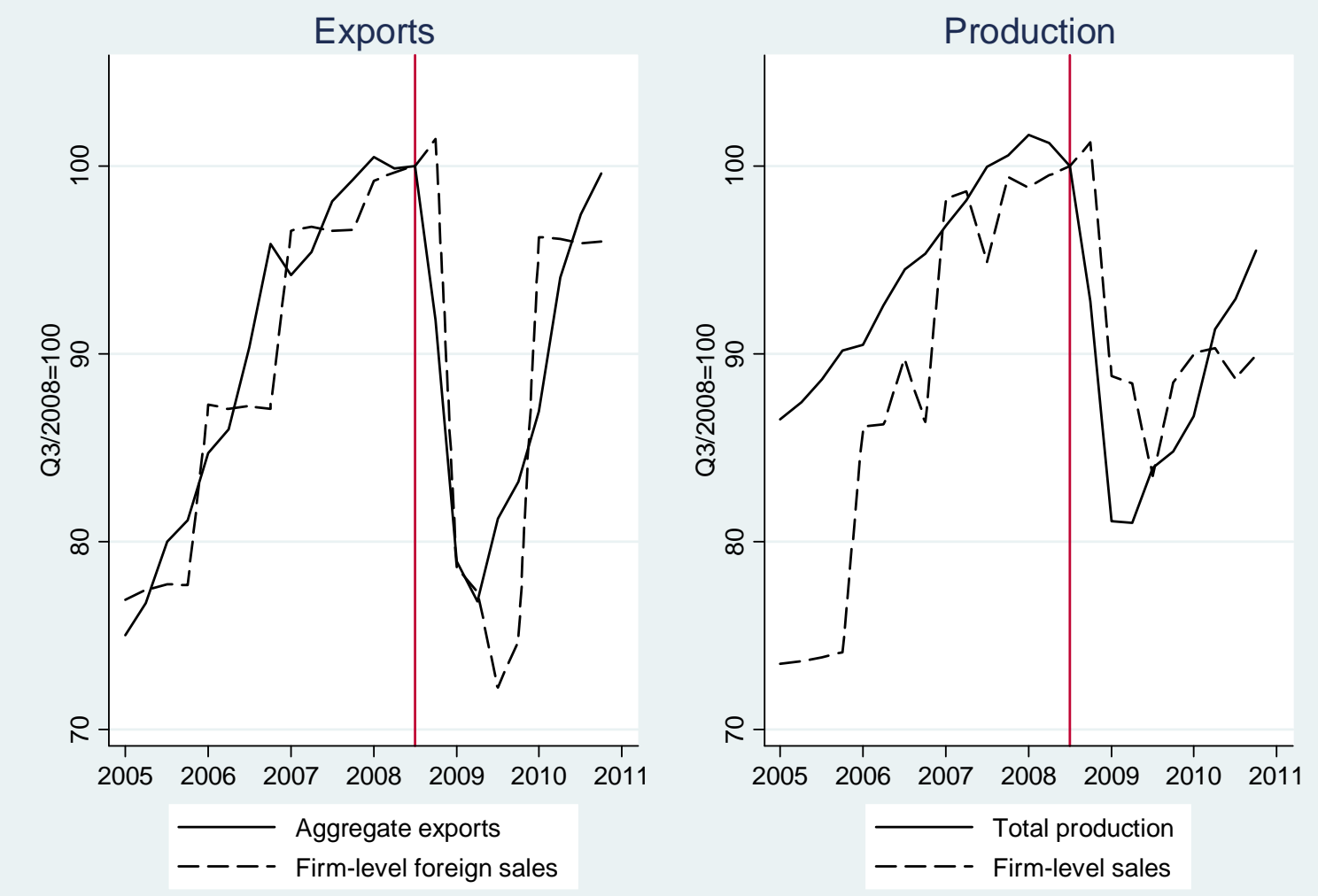

Notes: The graphs are based on quarterly data from the Bundesbank's credit register matched with the Bundesbank's corporate balance sheet statistics; the panel is unbalanced.

Source: Deutsche Bundesbank 
Figure 4: Bank Health and Lending
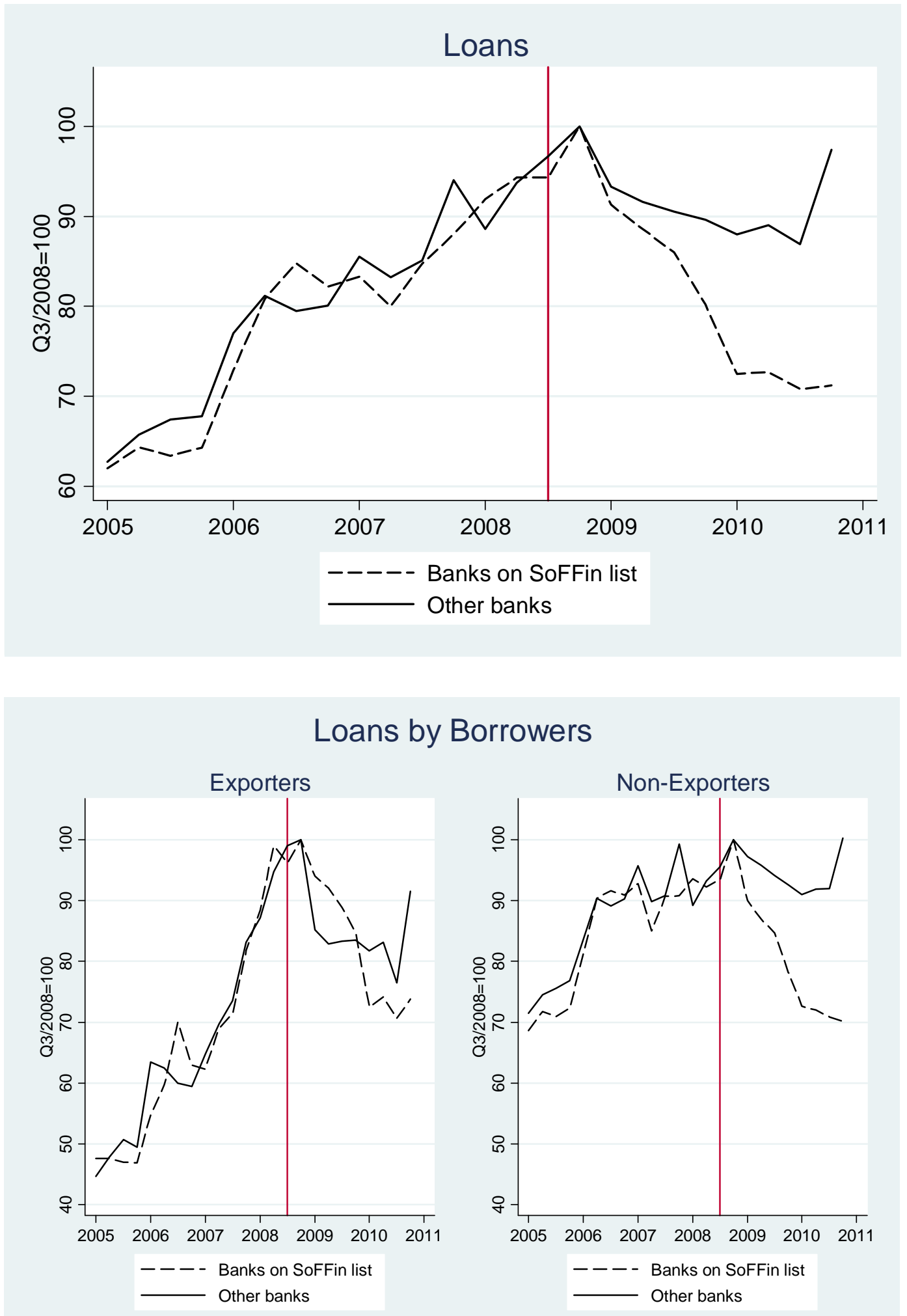

Notes: The quarterly data are taken from the Bundesbank's credit register (covering exposures in excess of $1.5 \mathrm{~m}$ euro).

Source: Deutsche Bundesbank 
Table 1: Information on Matched Data Sets, 2005-2010

\begin{tabular}{|c|c|c|c|c|}
\hline & MiMiK & $\begin{array}{l}\text { MiMiK - } \\
\text { Ustan }\end{array}$ & $\begin{array}{l}\text { MiMiK - } \\
\text { BAKIS }\end{array}$ & $\begin{array}{c}\text { MiMiK - } \\
\text { Ustan - } \\
\text { BAKIS }\end{array}$ \\
\hline & (1) & (2) & (3) & (4) \\
\hline Loan-quarter pairs & 933,612 & 799,104 & 804,517 & 692,909 \\
\hline Firms & 14,854 & 14,545 & 14,675 & 14,380 \\
\hline of which: Exporters & & 5,839 & & 5,787 \\
\hline Banks & 2,275 & 2,170 & 1,657 & 1,590 \\
\hline $\begin{array}{l}\text { Mean number of loans per } \\
\text { firm }\end{array}$ & 3.13 & 3.25 & 2.79 & 2.88 \\
\hline $\begin{array}{l}\text { Mean share of largest lender } \\
\text { per firm }\end{array}$ & 0.755 & 0.744 & 0.774 & 0.766 \\
\hline $\begin{array}{l}\text { Mean number of loans per } \\
\text { bank }\end{array}$ & 25.37 & 22.90 & 27.63 & 24.90 \\
\hline $\begin{array}{l}\text { Mean share of largest } \\
\text { borrower per bank }\end{array}$ & 0.546 & 0.552 & 0.515 & 0.525 \\
\hline Mean loan value $(1,000 €)$ & 8,144 & 8,147 & 7,983 & 8,045 \\
\hline Median loan value $(1,000 €)$ & 2,250 & 2,305 & 2,205 & 2,268 \\
\hline Sales (bn. €) & & 8,190 & & 7,940 \\
\hline of which: Exports (bn. $€$ ) & & 2,160 & & 2,100 \\
\hline
\end{tabular}

Notes: The table describes samples based on matched data sets. All data have been obtained from the Deutsche Bundesbank. MiMiK is the credit register; Ustan is the corporate balance sheet statistics; BAKIS is the prudential information system on banks. 
Table 2: Credit Exposure and Exports, 2005-2010

\begin{tabular}{|c|c|c|c|c|c|c|c|c|c|}
\hline Dependent variable: & $\begin{array}{c}\Delta \text { Log } \\
\text { Exports }_{t}\end{array}$ & $\begin{array}{c}\Delta \text { Log } \\
\text { Export } \\
\text { Share }_{t}\end{array}$ & $\begin{array}{c}\Delta \text { Log } \\
\text { Domestic } \text { Sales }_{t}\end{array}$ & $\begin{array}{c}\Delta \text { Log Total }^{\Delta} \\
\text { Sales }_{t}\end{array}$ & $\begin{array}{c}\Delta \text { Log Total } \\
\text { Sales }_{\mathbf{t}} \\
\text { (Non- } \\
\text { Exporter) }^{\text {Non }}\end{array}$ & $\begin{array}{c}\Delta \text { Log Total } \\
\text { Sales }_{\mathrm{t}} \\
\text { (Exporter) }^{\text {Expor }}\end{array}$ & $\begin{array}{c}\Delta \text { Log } \\
\text { Exports }\end{array}$ & $\begin{array}{c}\Delta \text { Log } \\
\text { Exports }_{t}\end{array}$ & $\begin{array}{c}\Delta \text { Log } \\
\text { Exports }\end{array}$ \\
\hline & (1) & (2) & (3) & (4) & (5) & (6) & (7) & (8) & (9) \\
\hline $\begin{array}{l}\Delta \text { Log Total Firm } \\
\text { Credit }_{\text {-1 }}\end{array}$ & $\begin{array}{l}-0.018 \\
(0.039)\end{array}$ & $\begin{array}{l}-0.001 \\
(0.001)\end{array}$ & $\begin{array}{l}0.018 * * \\
(0.006)\end{array}$ & $\begin{array}{l}0.021 * * \\
(0.005)\end{array}$ & $\begin{array}{l}0.029^{* *} \\
(0.007)\end{array}$ & $\begin{array}{c}0.012 \# \\
(0.007)\end{array}$ & $\begin{array}{l}-0.054 \\
(0.042)\end{array}$ & & \\
\hline$\Delta$ Log Firm Credit $_{\text {t-1 }}$ & & & & & & & & $\begin{array}{r}0.044 \# \\
(0.024)\end{array}$ & $\begin{array}{r}0.041 \# \\
(0.024)\end{array}$ \\
\hline Industry-Time FE? & Yes & Yes & Yes & Yes & Yes & Yes & Yes & Yes & Yes \\
\hline Bank FE? & No & No & No & No & No & No & No & No & Yes \\
\hline Firm FE? & No & No & No & No & No & No & Yes & No & No \\
\hline \# Observations & 13,252 & 13,252 & 34,235 & 34,235 & 20,983 & 13,252 & 13,252 & 31,391 & 31,391 \\
\hline $\mathbf{R}^{2}$ & 0.007 & 0.001 & 0.021 & 0.032 & 0.016 & 0.106 & 0.307 & 0.078 & 0.100 \\
\hline
\end{tabular}

Notes: OLS estimation. The unit of observation is a firm in columns 1-7 and a bank-firm pair in columns 8-9. Data cover the period 2005-2010 at annual frequency. Robust standard errors in parentheses. $* *, *$ and \# denote significant at the $1 \%, 5 \%$ and $10 \%$ level, respectively. 
Table 3: Measures of Bank Health

$\underline{\text { Summary Statistics }}$

\begin{tabular}{|l|c|c|c|c|c|}
\hline & Obs. & Mean & Std. Dev. & Min & Max \\
\hline SoFFin & 692,909 & 0.189 & 0.392 & 0 & 1 \\
\hline SoFFin (w/ subsidiaries) & 692,909 & 0.282 & 0.450 & 0 & 1 \\
\hline EBA & 692,909 & 0.303 & 0.460 & 0 & 1 \\
\hline EBA (w/ subsidiaries) & 692,909 & 0.445 & 0.497 & 0 & 1 \\
\hline
\end{tabular}

Correlation Matrix

\begin{tabular}{|l|l|l|l|l|}
\hline & SoFFin & $\begin{array}{l}\text { SoFFin } \\
(\mathbf{w} /)\end{array}$ & EBA & EBA (w/) \\
\hline SoFFin & 1.000 & & & \\
\hline SoFFin (w/ subsidiaries) & 0.771 & 1.000 & & \\
\hline EBA & 0.460 & 0.265 & 1.000 & \\
\hline EBA (w/ subsidiaries) & 0.341 & 0.495 & 0.738 & 1.000 \\
\hline
\end{tabular}

Notes: The unit of observation is a bank-firm pair. Data cover the period Q1/2005-Q4/2010. Banks covered by the special financial market stabilization fund (SoFFin) and the European Banking Authority (EBA) are listed in Appendix 2. 
Table 4: Bank Health and Lending, 2009

\begin{tabular}{|c|c|c|c|c|}
\hline Dependent variable: & \multicolumn{4}{|c|}{$\Delta$ Log Firm Credit } \\
\hline & (1) & (2) & (3) & (4) \\
\hline SoFFin & $\begin{array}{l}-0.102^{* *} \\
(0.019)\end{array}$ & & & \\
\hline SoFFin (w/ subsidiaries) & & $\begin{array}{l}-0.081 \text { ** } \\
(0.017)\end{array}$ & & \\
\hline EBA & & & $\begin{array}{l}-0.021 \\
(0.017)\end{array}$ & \\
\hline EBA (w/ subsidiaries) & & & & $\begin{array}{l}-0.030 \# \\
(0.015)\end{array}$ \\
\hline Firm FE? & \multicolumn{4}{|c|}{ Yes } \\
\hline \# Firms & \multicolumn{4}{|c|}{10,050} \\
\hline \# Observations & \multicolumn{4}{|c|}{27,086} \\
\hline $\mathbf{R}^{2}$ & 0.119 & 0.118 & 0.117 & 0.117 \\
\hline
\end{tabular}

Notes: OLS estimation. The unit of observation is a bank-firm pair. Robust standard errors in parentheses. $* *, *$ and $\#$ denote significant at the $1 \%, 5 \%$ and $10 \%$ level, respectively. 
Table 5: Credit Exposure and Exports, 2009

\begin{tabular}{|c|c|c|c|c|c|c|c|c|}
\hline Dependent variable: & $\begin{array}{c}\Delta \text { Log } \\
\text { Exports }_{t}\end{array}$ & $\begin{array}{c}\Delta \text { Log } \\
\text { Exports }_{t}\end{array}$ & $\begin{array}{c}\Delta \mathrm{Log} \\
\text { Domestic } \\
\text { Sales }_{\mathrm{t}}\end{array}$ & $\begin{array}{c}\Delta \log \\
\text { Domestic } \\
\text { Sales }_{t}\end{array}$ & $\begin{array}{c}\Delta \text { Log Total }^{-} \text {Sales }_{t} \\
\text { sal }\end{array}$ & $\begin{array}{c}\Delta \text { Log Total }^{\text {Log Tes }} \\
\text { Sal }_{\mathbf{t}}\end{array}$ & $\begin{array}{l}\Delta \text { Log } \\
\text { Sales }_{\mathrm{t}}\end{array}$ & $\begin{array}{l}\Delta \text { Log } \\
\text { Sales }\end{array}$ \\
\hline & OLS & $2 \mathrm{SLS}$ & OLS & $2 \mathrm{SLS}$ & OLS & $2 \mathrm{SLS}$ & OLS & 2 SLS \\
\hline & $(1)$ & $(2)$ & (3) & (4) & $(5)$ & $(6)$ & (7) & (8) \\
\hline$\Delta$ Log Firm Credit F $1_{1}$ & $\begin{array}{l}-0.002 \\
(0.034)\end{array}$ & $\begin{array}{c}0.076 \\
(1.393)\end{array}$ & $\begin{array}{l}0.011^{* *} \\
(0.003)\end{array}$ & $\begin{array}{c}0.097 * * \\
(0.031) \\
\end{array}$ & $\begin{array}{l}0.009 * * \\
(0.002)\end{array}$ & $\begin{array}{c}0.076^{* *} \\
(0.026) \\
\end{array}$ & $\begin{array}{r}0.010 \# \\
(0.005)\end{array}$ & $\begin{array}{c}0.105 \\
(0.072) \\
\end{array}$ \\
\hline & \multicolumn{8}{|c|}{ First Stage for $\Delta$ Log Total Firm Credit } \\
\hline SoFFin $_{t-1}$ & & $\begin{array}{l}-0.077 * \\
(0.034) \\
\end{array}$ & & $\begin{array}{l}-0.167 * * \\
(0.019) \\
\end{array}$ & & $\begin{array}{l}-0.165^{* *} \\
(0.018) \\
\end{array}$ & & $\begin{array}{l}-0.168^{* *} \\
(0.013)\end{array}$ \\
\hline Industry FE? & Yes & Yes & Yes & Yes & Yes & Yes & No & No \\
\hline Industry-Destination FE? & No & No & No & No & No & No & Yes & Yes \\
\hline \# Observations & 9,465 & 9,465 & 26,567 & 26,567 & 26,578 & 26,578 & 53,215 & 53,215 \\
\hline $\mathbf{R}^{2}$ & 0.010 & 0.012 & 0.086 & 0.031 & 0.155 & 0.106 & 0.006 & 0.009 \\
\hline
\end{tabular}

Notes: The dependent variable is specified at the top of each column. Log sales refers to (the log of) firm sales by destination (domestic, foreign). All estimates are weighted least squares using the number of observations per industry as weights. The unit of observation is a bank-firm pair. Robust standard errors are in parentheses. ${ }^{* *}, *$ and \# denote significant at the $1 \%, 5 \%$ and $10 \%$ level, respectively. 
Table 6: Robustness Checks for IV Regressions

\begin{tabular}{|c|c|c|c|c|c|c|c|c|}
\hline Dependent variable: & $\begin{array}{c}\Delta \text { Log } \\
\text { Exports }_{t}\end{array}$ & $\begin{array}{c}\Delta \text { Log } \\
\text { Exports }_{t}\end{array}$ & $\begin{array}{c}\Delta \text { Log } \\
\text { Domestic } \\
\text { Sales }_{t}\end{array}$ & $\begin{array}{c}\Delta \text { Log } \\
\text { Domestic } \text { Sales }_{t} \\
\end{array}$ & $\begin{array}{c}\Delta \text { Log Total } \\
\text { Sales }_{t}\end{array}$ & $\begin{array}{c}\Delta \text { Log Total } \\
\text { Sales }_{t}\end{array}$ & $\begin{array}{l}\Delta \text { Log } \\
\text { Sales }_{t}\end{array}$ & $\begin{array}{l}\Delta \text { Log } \\
\text { Sales }_{t}\end{array}$ \\
\hline & OLS & 2SLS & OLS & 2SLS & OLS & 2SLS & OLS & 2SLS \\
\hline & $(1)$ & $(2)$ & (3) & $(4)$ & $(5)$ & $(6)$ & $(7)$ & $(8)$ \\
\hline & \multicolumn{8}{|c|}{ Using SoFFin $_{t-1}$ as Instrument for $\Delta$ Log Total Firm Credit $t_{t-1}$} \\
\hline Baseline & \begin{tabular}{|l|}
-0.002 \\
$(0.034)$ \\
\end{tabular} & $\begin{array}{c}0.076 \\
(1.393) \\
\end{array}$ & $\begin{array}{l}0.011^{* *} \\
(0.003)\end{array}$ & $\begin{array}{l}0.097 * * \\
(0.031)\end{array}$ & $\begin{array}{l}0.009^{* *} \\
(0.002)\end{array}$ & $\begin{array}{l}0.076^{* *} \\
(0.026) \\
\end{array}$ & $\begin{array}{r}0.010 \# \\
(0.005) \\
\end{array}$ & $\begin{array}{c}0.105 \\
(0.072) \\
\end{array}$ \\
\hline Adding Firm Controls & \begin{tabular}{|l|}
-0.042 \\
$(0.028)$ \\
\end{tabular} & $\begin{array}{c}0.426 \\
(1.397) \\
\end{array}$ & $\begin{array}{l}0.006^{* *} \\
(0.002)\end{array}$ & $\begin{array}{l}0.092 * * \\
(0.037)\end{array}$ & $\begin{array}{l}0.006^{* *} \\
(0.002)\end{array}$ & $\begin{array}{c}0.047 \# \\
(0.028) \\
\end{array}$ & $\begin{array}{c}0.001 \\
(0.004)\end{array}$ & $\begin{array}{c}0.173 \# \\
(0.091) \\
\end{array}$ \\
\hline \multirow[t]{2}{*}{ Exporters Only } & \begin{tabular}{|l|}
-0.002 \\
$(0.034)$ \\
\end{tabular} & $\begin{array}{c}0.076 \\
(1.393) \\
\end{array}$ & $\begin{array}{l}0.016^{* *} \\
(0.005)\end{array}$ & $\begin{array}{r}0.484 \# \\
(0.259) \\
\end{array}$ & $\begin{array}{l}0.014 * * \\
(0.004)\end{array}$ & $\begin{array}{c}0.335 \\
(0.219) \\
\end{array}$ & $\begin{array}{c}0.004 \\
(0.014) \\
\end{array}$ & $\begin{array}{c}0.569 \\
(0.540) \\
\end{array}$ \\
\hline & \multicolumn{8}{|c|}{ Using Alternative Instruments for $\Delta$ Log Total Firm Credit $t_{t-1}$} \\
\hline SoFFin (w/ subsidiaries) & \begin{tabular}{|l|}
-0.002 \\
$(0.034)$ \\
\end{tabular} & $\begin{array}{c}0.386 \\
(2.724) \\
\end{array}$ & $\begin{array}{l}0.011^{* *} \\
(0.003)\end{array}$ & $\begin{array}{l}0.093 * * \\
(0.034) \\
\end{array}$ & $\begin{array}{l}0.009^{* *} \\
(0.002)\end{array}$ & $\begin{array}{r}0.059^{*} \\
(0.029) \\
\end{array}$ & $\begin{array}{c}0.010 \# \\
(0.005) \\
\end{array}$ & $\begin{array}{c}0.109 \\
(0.078) \\
\end{array}$ \\
\hline EBA & \begin{tabular}{|l|}
-0.002 \\
$(0.034)$ \\
\end{tabular} & $\begin{array}{c}1.003 \\
(1.296) \\
\end{array}$ & $\begin{array}{l}0.011^{* *} \\
(0.003)\end{array}$ & $\begin{array}{l}0.260 * * \\
(0.078)\end{array}$ & $\begin{array}{l}0.009 * * \\
(0.002)\end{array}$ & $\begin{array}{l}0.246^{* *} \\
(0.071)\end{array}$ & $\begin{array}{c}0.010 \# \\
(0.005) \\
\end{array}$ & $\begin{array}{c}0.211 \\
(0.147)\end{array}$ \\
\hline EBA (w/ subsidiaries) & \begin{tabular}{|l|}
-0.002 \\
$(0.034)$ \\
\end{tabular} & $\begin{array}{l}-0.072 \\
(1.208)\end{array}$ & $\begin{array}{l}0.011^{* *} \\
(0.003)\end{array}$ & $\begin{array}{l}0.189 * * \\
(0.059)\end{array}$ & $\begin{array}{l}0.009 * * \\
(0.002)\end{array}$ & $\begin{array}{l}0.171 * * \\
(0.052)\end{array}$ & $\begin{array}{r}0.010 \# \\
(0.005) \\
\end{array}$ & $\begin{array}{c}0.133 \\
(0.122) \\
\end{array}$ \\
\hline
\end{tabular}

Notes: Each entry in the table represents the coefficient on the firm credit variable from a separate regression. The dependent variable is specified at the top of each column. Log sales refers to (the log of) firm sales by destination (domestic, foreign). Firm controls include log employment, log age, and binary dummy variables for multinationals, legal status of the firm and firm location. All estimates are weighted least squares using the number of observations per industry as weights. The unit of observation is a bank-firm pair. Robust standard errors are in parentheses. **, * and \# denote significant at the $1 \%, 5 \%$ and $10 \%$ level, respectively. 
Table 7: Bank Lending and Firm Export Status, 2009

\begin{tabular}{|c|c|c|c|c|c|c|c|c|}
\hline \multirow[t]{2}{*}{ Dependent variable: } & \multicolumn{4}{|c|}{$\Delta$ Log Firm Credit } & \multicolumn{2}{|c|}{ Entry } & \multicolumn{2}{|c|}{ Exit } \\
\hline & (1) & $(2)$ & (3) & (4) & $(5)$ & (6) & (7) & (8) \\
\hline SoFFin & \begin{tabular}{|l}
$-0.153 * *$ \\
$(0.034)$ \\
\end{tabular} & $\begin{array}{l}-0.139 * * \\
(0.030)\end{array}$ & \begin{tabular}{|l|}
$-0.148^{* *}$ \\
$(0.035)$ \\
\end{tabular} & $\begin{array}{l}-0.134 * * \\
(0.031) \\
\end{array}$ & $\begin{array}{l}-0.001 \\
(0.004)\end{array}$ & $\begin{array}{l}-0.003 \\
(0.003)\end{array}$ & $\begin{array}{l}-0.040 \\
(0.031)\end{array}$ & $\begin{array}{l}-0.030 \\
(0.033)\end{array}$ \\
\hline SoFFin $\times$ Exporter & $\begin{array}{l}0.080^{* *} \\
(0.029)\end{array}$ & & $\begin{array}{l}0.081 * * \\
(0.030)\end{array}$ & & $\begin{array}{l}-0.001 \\
(0.003)\end{array}$ & & $\begin{array}{c}0.019 \\
(0.021)\end{array}$ & \\
\hline $\begin{array}{l}\text { SoFFin } \times \text { Log Export } \\
\text { Share }\end{array}$ & & $\begin{array}{l}0.153^{*} \\
(0.075)\end{array}$ & & $\begin{array}{l}0.158^{*} \\
(0.074)\end{array}$ & & $\begin{array}{l}-0.008 \\
(0.008)\end{array}$ & & $\begin{array}{l}-0.034 \\
(0.033)\end{array}$ \\
\hline Exporter & \begin{tabular}{|l|}
-0.023 \\
$(0.018)$ \\
\end{tabular} & & \begin{tabular}{|l|}
-0.030 \\
$(0.019)$ \\
\end{tabular} & & $\begin{array}{l}-0.008 * * \\
(0.003) \\
\end{array}$ & & $\begin{array}{l}0.098^{* *} \\
(0.008)\end{array}$ & \\
\hline Log Export Share & & $\begin{array}{l}-0.073 \\
(0.060)\end{array}$ & & $\begin{array}{l}-0.094 \\
(0.060) \\
\end{array}$ & & $\begin{array}{c}0.006 \\
(0.006) \\
\end{array}$ & & $\begin{array}{l}0.353^{* *} \\
(0.024) \\
\end{array}$ \\
\hline Industry FE? & Yes & Yes & Yes & Yes & Yes & Yes & Yes & Yes \\
\hline $\begin{array}{l}\text { Additional Firm } \\
\text { Controls? }\end{array}$ & No & No & Yes & Yes & No & No & No & No \\
\hline \# Observations & 27,086 & 27,086 & 27,086 & 27,086 & 34,185 & 33,060 & 34,185 & 33,060 \\
\hline $\mathbf{R}^{2}$ & 0.011 & 0.011 & 0.018 & 0.018 & 0.004 & 0.004 & 0.109 & 0.11 \\
\hline
\end{tabular}

Notes: OLS estimation. The dependent variable is specified at the top of each column. The unit of observation is a bank-firm pair. Firm controls include log employment, log age, and binary dummy variables for multinationals, legal status of the firm and firm location. Robust standard errors in parentheses. $* *, *$ and $\#$ denote significant at the $1 \%, 5 \%$ and $10 \%$ level, respectively. 

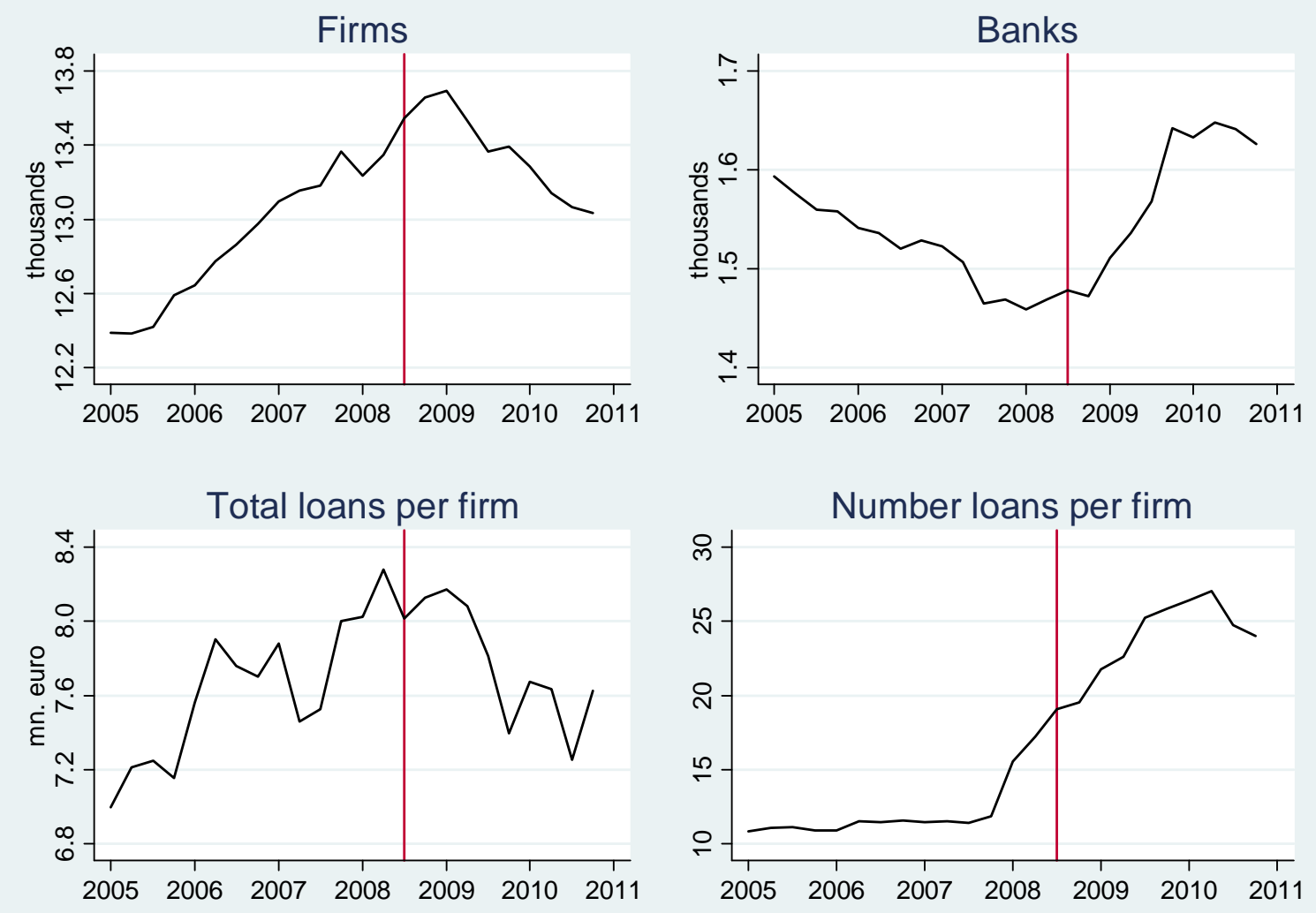

Notes: The graphs are based on quarterly data from various matched data sources.

Source: Deutsche Bundesbank 
Appendix 2: Lists of Banks

Recapitalized German Banks Using the Financial Markets Stabilization Fund (SoFFin)

Aareal Bank

BayernLB

Commerzbank AG

Corealcredit Bank AG

Düsseldorfer Hypothekenbank

HSH Nordbank

Hypo Real Estate

IKB Deutsche Industriebank

Volkswagen Bank

WestLB

German Banks Covered by the European Banking Authority (EBA) Stress Test Exercise

BayernLB

Commerzbank AG

Dekabank

Deutsche Bank AG

DZ Bank AG

Helaba

HSH Nordbank

Hypo Real Estate

Landesbank Berlin

LBBW

NordLB

WestLB

WGZ Bank

Notes: Banks are listed in alphabetical order. 